\title{
„Studia Poradoznawcze" 2013, Wydawnictwo Naukowe DSW, Wrocław 2013, ss. 349
}

Praca z ludźmi, bez względu na swój rodzaj i zakres, wymaga (samo)świadomości i głębokiego namysłu nad intencjami obu stron relacji. Warunkiem koniecznym, choć niewystarczającym, jest jednak w tego typu pracy specjalistyczna wiedza o człowieku, relacjach międzyludzkich, społecznych itp. Ma ona na celu zrozumieć, wyjaśniać, planować, interpretować podejmowane działania pomocowe, edukacyjne, opiekuńcze czy też poradnicze. Jednym z elementów, które pomagają wiedzę instytucjonalizować (na uniwersytetach, w instytutach badawczych), ale też upraktyczniać, są czasopisma naukowe. Jednym z nich są ukazujące się od 2012 roku „Studia Poradoznawcze” („Journal of Counsellogy”), będące rocznikiem redagowanym przez Naukowe Towarzystwo Poradoznawcze (redaktor naczelną jest prof. Alicja Kargulowa) i wydawanym przez DSW we Wrocławiu.

Pismo podejmuje i znacząco rozwija myśl poradoznawczą, sięgając po kwestie (wielodyscyplinarnych) badań nad poradnictwem, zagadnienia dotyczące jego znaczenia dla jednostki i społeczeństwa czy prezentując koncepcje i refleksje polskich oraz zagranicznych badaczy². Czasopismo ma międzynarodową Radę Naukową ${ }^{3}$ oraz redaktorów, będących wybitnymi specjalistami z zakresu poradoznawstwa. Udział tych badaczy w tworzeniu

1 Pismo wydawane jest w formie elektronicznej w polskiej i angielskiej wersji językowej. Dla przyszłych autorów ważna może okazać się informacja, że streszczenia publikowanych prac są dostępne w międzynarodowej bazie danych The Central European Journal of Social Sciences and Humanities.

2 Składa się z pięciu działów: (1) Studia i rozprawy, (2) Komunikaty z badań, (3) Rekomendacje dla praktyki poradnictwa, (4) Recenzje, (5) Aktualności i kronika.

3 Do prac w Radzie Naukowej pisma zostały zaproszone najważniejsze osoby, zajmujące się tematem poradnictwa z całego świata: B.-J. Ertelt, A. Di Fabio, J. Guichard, G. Jacobs, S. Kriwas, R. Kwaśnica, L. Nota, M. Savickas, E. Solarczyk-Ambrozik, B. Śliwerski, B. Wojtasik, R. A. Young. 
profilu pisma jest nie do przecenienia, bowiem aktywnie włączają się w prace nad zakresem podejmowanych tematów i sposobem ich rozumienia. „Studia Poradoznawcze 2013" są efektem takich działań, bowiem redaktor naczelna przedstawia czytelnikom bardzo ciekawą dyskusję dotyczącą poradoznawstwa, sprowokowaną przez listy recenzenckie dwóch członków Rady Naukowej - Jeana Guicharda i Spyrosa Kriwasa. Dyskusja ta staje się osią, wokół której umieszczone są pozostałe artykuły numeru „Studiów”. Wprowadzenie $\mathrm{w}$ temat to słowa Violetty Drabik-Podgórnej, która „w imieniu redakcji”, nawiązując do pracy Bogusława Śliwerskiego ${ }^{4}$, zadaje pytania podstawowe o definicję roli poradnictwa, poradoznawstwa, doradcy i poradoznawcy. Tekst Myśleć jak poradoznawca..., jak sama autorka zauważa, raczej problem otwiera, niż daje gotowe odpowiedzi czy rozwiązania (s. 11).

Odpowiedzi na te problemy próbują natomiast sformułować badaczki i badacze, współautorzy kolejnego tekstu w „Studiach”, Profesorowi Jeanowi Guichardowi w odpowiedzi $i^{5}$. J. Guichard przysłał list prezentujący stanowisko w sprawie zadań poradoznawstwa prof. A. Kargulowej, która podzieliła się jego treścią z badaczkami z Polski: Alicją Czerkawską, Joanną Kłodkowską, Elżbietą Siarkiewicz, Darią Zielińską-Pękał i Edytą Zierkiewicz. A. Kargulowa wypowiedzi zebrała, przytaczając w znaczących fragmentach interesującą dyskusję dotyczącą „trudności w zidentyfikowaniu specyfiki poradnictwa; teorii a praktyka poradnictwa; poradnictwa i innych praktyk pomocowych; skutków, efektów ubocznych, zakłóceń w codzienności poradniczej praktyki” (s. 17). Jest to wciąż aktualna debata, J. Guichard „dał bowiem do zrozumienia, że dokładniejsze określenie przedmiotu badań jest ciągle ważne, gdyż różnicując się w założeniach i realizacji, poradnictwo ostatecznie przybiera kształt sieci i przez to staje się - używając słów Bruno Latoura - jednocześnie realne jak natura, narracyjne jak dyskurs i kolektywne jak społeczeństwo" (s. 17). Autor odwołuje się do kategorii zaproponowanych przez Latoura, tj. dychotomii procesów translacji (przeniesienia) i puryfikacji (oczyszczania) ${ }^{7}$. Dychotomia ta łagodzona jest przez różnego typu procesy mediacji. A. Kar-

4 B. Śliwerski, Myśleć jak pedagog, GWP, Gdańsk 2010.

Jean Guichard jest profesorem psychologii, byłym pracownikiem INETOP-u (Institut national d'etude du travail et d'orientation professionnelle) w Paryżu. W 2013 roku został kierownikiem Katedry UNESCO Całożyciowego Poradnictwa Zawodowego w Uniwersytecie Wrocławskim.

6 B. Latour, Nigdy nie byliśmy nowocześni. Studium z antropologii symetrycznej, przeł. M. Gulda, Oficyna Naukowa, Warszawa 2011, s. 16.

7 Pojawia się tu także odwołanie do koncepcji społeczeństwa sieci Manuela Castellsa (M. Castells, Społeczeństwo sieci, tłum. M. Marody i in., Wydawnictwo Naukowe PWN, Warszawa 2008), ale też do prac Michaela Foucaulta. 
gulowa pisze: „Na łamach naszego pisma włączamy się w społeczną mediację poprzez analizę poradnictwa, traktowanego jako relacja międzyludzka, jako działanie podejmowane wobec drugiego oraz jako działalność powoływanych instytucji pomocowych" (s. 18) ${ }^{8}$. Guichard powołuje się na pojemną analitycznie kategorię homo consultans, która pozwala na zrozumienie podmiotowości ludzkiej i osobistych ukierunkowań/działań życiowych. E. Zierkiewicz w tym kontekście stwierdza, że „celem badań staje się tutaj kultura terapeutyczna (»odwstydzająca« szeroko rozumiane cierpienie w sferze publicznej, promująca indywidualizm i nowe narracje tożsamościowe - zindywidualizowane opowieści o radzeniu sobie z problemami [z naciskiem na problemy, a nie na radzenie sobie]" (s. 24). J. Kłodkowska natomiast zastanawia się nad przydatnością zwrotu „radzenie sobie”, co w pewnym sensie pogłębia cały dyskurs metodologiczny poradoznawstwa. Za Stevanem E. Hobfollem ${ }^{9}$ proponuje, by zjawisko radzenia sobie ujmować z perspektywy „uwypuklającej" bycie jednostki w kontekście społecznym i współzależne z naturą jej wysiłków zaradczych. D. Zielińska-Pękał pyta zaś o rolę poradnictwa zapośredniczonego i pokrewne/bliskie/niejednoznaczne formy poradnictwa, przez co „dotyka [...] tutaj kwestii związanej z zsubiektywizowaniem przedmiotu poradoznawstwa" (s. 29). Badaczka opisuje także interesujące zjawiska polegające na generowaniu (wytwarzaniu, powodowaniu) problemów odczuwanych przez ludzi, jak również ich sepizowaniu (unieważnianiu) ${ }^{10}$ (s. 37).

Kwestię tożsamości subdyscypliny porusza także A. Kargulowa w artykule O potrzebie badań poradoznawczych. Ku antropologii poradnictwa. Autorka za punkt wyjścia obiera swoistą potrzebę społeczną, która powoduje, że coraz częściej, chętniej i liczniej korzystamy z usług doradczych różnego rodzaju. Czym zatem jest porada/poradnictwo? Badaczka odpowiada: „Poradnictwo, wychodząc poza określone struktury, nie tylko przyjęło kształt sieci, lecz stało się przepływem wiedzy i idei, strumieniem ludzkich problemów, dyskursów naukowych, praktyk pomocowych, różnych wspomagających działań oraz obiektów materialnych i urządzeń technicznych, które przesyłają, selekcjonują” (s. 90). Zauważa ponadto: „Nie oznacza to jednak, że po-

8 Są to zatem rozważania z zakresu socjologii wiedzy (nie tylko z powodu odwołań do B. Latoura). Kargulowa wspomina toczone w latach 1979-1995 interdyscyplinarne dyskusje w ramach ogólnopolskiego seminarium naukowego „Poradnictwo we współczesnym społeczeństwie” organizowanego przez Instytut Pedagogiki i Instytut Psychologii Uniwersytetu Wrocławskiego.

9 S. E. Hobfoll, Stres, kultura i społeczność: psychologia i filozofia stresu, GWP, Gdańsk 2006, s. 139.

10 SEP (od ang. Somebody Else's Problem) oznacza problem kogoś innego. 
radnictwo jest bytem społecznym wyłącznie o wysokim morale, że wszystkie działania doradców są zorientowane na czynienie powszechnego dobra i przechowują poradnicze teksty" (s. 90-91). Poradoznawstwo, jako subdyscyplina naukowa, w związku z tym „akcentuje kulturowy charakter wspomagania jednych ludzi przez drugich i rolę poradnictwa jako wytworu kultury oraz wskazuje na jego związki z antropologią kulturową" (s. 97).

Drugi ważny wątek podejmowany w "Studiach” dotyczy aktualnego problemu społecznego, jakim jest uczenie się oraz poradnictwo karier i rozwój zawodowy. Pisze o nich m.in. Anna Bilon w tekście Współczesne tendencje $w$ badaniach poradnictwa kariery. Autorka dokonuje przeglądu teorii i badań dotyczących rozwoju karier w perspektywie teorii strukturacji Anthony'ego Giddensa. Inny wątek porusza Monika Noworolnik-Mastalska w artykule Rozwój profesjonalny jako uczenie się w relacjach. Autorka zwraca uwagę na szeroki kontekst społeczno-kulturowy uczenia się, który powinien znaleźć zastosowanie zarówno w praktyce poradniczej, jak i pomocowej. Tom Luken dopełnia temat, próbując odpowiedzieć na pytania zawarte w artykule Przygotowanie do konstruowania kariery (career learning) - czy rzeczywiście zmierzamy $w$ dobrym kierunku? Tekst polemizuje $\mathrm{z}$ aktualnymi rozwiązaniami w zakresie rozwoju zawodowego, odwołując się do ustaleń współczesnej psychologii rozwojowej i neuropsychologii. Jako rekomendację autor prezentuje fazowy model rozwoju kariery.

Międzynarodową perspektywę prezentują również autorzy tekstu Opinie doradców i opiekunów praktyk na temat ksztatcenia w obszarze wielokulturowości i sprawiedliwości społecznej - Sandra Collins, Nancy Arthur, Candace Brown, Barbara Kennedy. Jako praktycy podejmują problem relacji wiedzy praktycznej i teoretycznej dla rozwoju dyscypliny, kształcenia przyszłych doradców oraz kompetencji doradców (a także ich braków).

W Dziale Recenzji znaleźć można aktualne publikacje z obszaru poradnictwa i poradoznawstwa. B. Śliwerski zrecenzował pracę E. Siarkiewicz, E. Trębińskiej-Szumigraj i D. Zielińskiej-Pękał Edukacyjne prowokacje. Wykorzystanie etnografii performatywnej w procesie ksztatcenia doradców (Kraków 2012). Sokratis Spyridis przedstawił ocenę publikacji Bożeny Wojtasik Podstawy poradnictwa kariery. Poradnik dla nauczycieli (Warszawa 2011). Natomiast Marcin Szumigraj zaprezentował czytelnikom książkę Joanny Minty Od aktora do autora. Wspieranie młodzieży w konstruowaniu własnej kariery (Warszawa 2012).

W części „Studiów” poświęconej ważnym wydarzeniom związanych $\mathrm{z}$ rozwojem poradoznawstwa znalazły się sprawozdania $\mathrm{z}$ konferencji i realizacji stopni rozwoju naukowego poradoznawców (obrona doktoratu Joanny Kłodkowskiej, kolokwium habilitacyjne Barbary Skałbani). 
V. Drabik-Podgórna i Marek Podgórny opowiedzieli o obradach w ramach konferencji „Poradnictwo kariery i dialog dla zrównoważonego rozwoju” („Orientation, conseil et dialogue pour un développement humain durable"), która zorganizowana była przez Katedrę UNESCO Całożyciowego Poradnictwa Zawodowego w dniach 26-27 listopada 2013 roku we Wrocławiu. Natomiast Anna Paszkowska-Rogacz opisała udział w konferencji „Career Guidance for Social Justice, Prosperity and Sustainable Employment Challenges for the $21^{\text {st }}$ Century", odbywającej się w dniach 3-6 października 2012 roku w Mannheim. W ramach sesji tematycznej „Wspólne cele - różne podejścia: Doradztwo zawodowe na świecie" prof. Alicja Kargulowa i Anna Bilon przedstawiły na konferencji referat "Doradztwo zawodowe w Polsce - założenia teoretyczne i rozwiązania praktyczne”. A. Paszkowska-Rogacz w sesji „Konstruktywizm w doradztwie zawodowym - teoria i praktyka” zaprezentowała wyniki projektu badawczego "Gotowość do kariery uczniów szkół średnich a ich orientacja temporalna”. Elżbieta Moroń złożyła sprawozdanie z Naukowego Seminarium Poradoznawczego (24 stycznia 2013 roku w Kłodzku), na którym Spyros Kriwas wygłosił referat „Nauczyciel jako doradca". Ostatnim wydarzeniem naukowym przytoczonym przez J. Kłodkowską jest XV Letnia Szkoła Andragogów i Poradoznawców zorganizowana w Międzygórzu 20-24 maja 2013 roku.

„Studia Poradoznawcze 2013” są ważną inicjatywą naukową, która pozornie ma charakter zamknięty i jest przeznaczona jedynie dla poradozwnaców. W rzeczywistości, otwarta i bogata formuła czasopisma jest atrakcyjna nie tylko dla czytelników, ale też badaczy z pokrewnych (sub)dyscyplin. Czasopismo prezentuje bardzo interesujące artykuły i studia, cechujące się wysokim poziomem merytorycznym i warsztatowym. Teksty odwołują się do najnowszych badań, poruszają tematy jeszcze niezbadane, nowe, trudne. Zdecydowaną zaletą jest fakt, że koncepcja pisma jest bardzo spójna, co należy wpisać w poczet zasług Redakcji. Można i należy powiedzieć z całą stanowczością, że „Studia Poradoznawcze” są wyjątkowo wartościową pozycją na polskim, ale też międzynarodowym rynku czasopism naukowych.

Anna Kola 